\title{
THE EFFECTIVENESS OF TIME MANAGEMENT TRAINING AND STRESS CONFLICTING METHODS ON FAMILY COHESION AND WORK LIFE QUALITY USING GROUP TECHNIQUE
}

\author{
Mahsa Norouzi \\ Master of Public sector management, University of Shiraz \\ mahsanoroozi870@yahoo.com \\ Hamidreza Nourbakhsh \\ Master of MBA, University of Tehran \\ Mohammad Reza Javadi \\ Master of MBA, University of Babol
}

\begin{abstract}
This research is to investigate the usefulness of combined training of time management and stress conflicting strategies, on personnel's quality of work life and Family Cohesion. To access the end, among 340 people of research statistic society, 30 center personnel of southern Zagros Gas company who were in low class according to the quality of working life questionnaire (QWL) and family cohesion randomly were selected and randomly they subordinated in two groups; experimental group (15 people) and control group (15 people). Research tools are working life (QWL) and familial solidarity questionnaire. The research method is a pre-test and post-test design with a randomized control group. The Mancova results showed that incorporation teaching of time management and stress conflicting methods with group technique doesn't affect on quality of working life meaningfully but it affects on the balance dimension between work and life which is one of the working life quality components. These results indicate that combined education of time management and stress conflicting strategies is effective on family solidarity of employees.
\end{abstract}

Keywords: Quality of Working Life- Family Cohesion - Stress Conflicting- Time Management

\section{INTRODUCTION}

Membership in various organizations and continuous communication with them is one of the requirements of today's world. To do their duty, managers follow a process that involves: planning, organizing, monitoring, controlling, motivating, communicating, directing, and deciding. Therefore, organizations deal with different variables, and the coordination and association of these variables can be one of the principal tasks of managers. One of the key factors in advancing the goals of the organization is the working life quality. Quality of work life is a set of methods and tasks which help to increase and maintain employee satisfaction, and aims to improve working conditions and increase the efficiency of the organization (Sadri \& Di, 2006). The life quality can be viewed from two perspectives. From one perspective, the quality of life is the set of objective and real conditions in the organization such as job enrichment, supervisory democracy, commitment and safety of working conditions. From other perspective, the quality of life is examined from the employee's point of view, which is the perception of employees about safety, satisfaction and the possibility of growth within the organization (Ghasmzadeh, 2005).

Another variable that directly and indirectly can affect individuals in organizations is family cohesion. Family cohesion is a feeling of interdependence, bondage and emotional commitment that members of a family have in relation to each other (Olson, 1999).

Thus, the true wealth of each country is to have liable, decent, and grown people who are found in healthy and high-performing families. Today, many organizations have found that creating a balance between work and life of their employees, in practice, can promote job satisfaction and raise the level of creativity and production (Powers, 2004). 
The importance and priority of time has been considered for long time by scholars, as some of them have predicted and break its boundaries for achieving greater knowledge and control the time, and some people have predicted even for the coming years (Javaherzadeh, 2005).

Time management is one of the effective ways to reduce the amount of stress, and recently most management and psychology books have a lot of emphasis on scheduling. Time management is not something separated from the term management in the general sense and aims to avoid waste of time and provide disciplines. In the era of emotions and business stresses and competitive life, today's life is full of tension, pressure, time constraints, warning mistakes and desperate (Lazarus, Salehi and Bazrafshan translation, 2009).

Implementation of work life quality plans has reduced staff complaints and absenteeism rates, and increased employee positive attitudes and their participation in proposals programs (Sirgy, David and Philip, 2007).

This paper discusses practical methods that may increase family cohesion and the quality of working life.

The purpose of this study is to investigate the impact of integrated training of time management and stress conflicting methods in group technique on family cohesion and work life quality, identification of the impact of integrated training of time management and stress conflicting strategies on family cohesion, identifying the impact of integrated group training on time management And stress conflicting methods on the quality of work life.

\section{Research literature:}

Work life quality: Work life quality is a comprehensive program that enhances employee satisfaction, enhances their learning in the environment and helps them to manage and change (Mirkamali, Narenji Sani, 2008).

In a general definition, it can be said that the work life quality means the mental imagination and perception of an organization's employees of the physical and psychological desirability of their work environment, which will be measured differently by the indicators of working life due to the definition provided in each community or in each region of a country, because different regions of our country, have different subcultures with mental imagery about life and work. Despite the differences in perceptions of the working life quality, research shows that some indicators are same in most societies (Zare, 2008).

Family cohesion: feeling of solidarity, bondage and emotional commitment that members of a family have with each other (Olson, 1999). In the Lingern's point of view, Consistency is spending time and being together among family members. Families that are strong in this field regularly consider plans and times for group activities. This is difficult in practice, while it seems simple.

Job stress causes:

Job stress is a psychological process, resulting from the long-term pattern of unhealthy interactions between the individual and the environment (Blocher, 2000).

The causes and factors of occupational stress are as follows: 1. Under intense and working constantly 2. Conflict of the role and tension between the employees as the colleagues support and the abundance of workplace criticism 3. The lack of opportunities for individual expression or the presence of the environment in which the change and new initiative and work are not only not encouraged but also blamed. 4. Unrealistic expectations of their time and energy. 5. Having a job that involves a person and he will not have the opportunity to train or receive other in-service favors. 6. Personal and out-of-job conflicts such as family tensions, chronic health problems or financial problems (Corey \& Corey, 1998).

Among the physical stress causes, it can be included improper lighting, inappropriate ventilation and contaminants (such as smoke). The unpleasant or inappropriate environment not only makes you feel sick, but also slowly weakens the morale of other members who are forced to deal with these unfavorable conditions (Verapierfer, translated by Afroz, 2009).

Time management process

Time management is a process that consists of four distinct, but related phases as followed here:
A) commitment
b) analysis
c) planning
d) follow-up and re-analysis (Farner, 2001).

Submit Date: 11.02. 2018, Acceptance Date: 27.02.2018, DOI NO: 10.7456/1080MSE/110

Research Article - This article was checked by Turnitin 
Dinehart (1993) described collaborative management and job design as two major parameters in the work life quality program, and these two have been identified as two responses for worker anxiety, and he believes that using this two parameters, we can provide a highly motivated workforce.

Hartos and Power (2000) showed that there is a negative relationship between the feeling of family solidarity and aggressive behavior.

Victoria, Nomi (2006), in the study titled "The Investigation of the Relationship between Family Cohesion and Children's Behavioral Problems", conducted among 823 children aged 6 and 11 years concluded that family cohesion is associated with internal problems and children's attention. Dixie and Nikola (2009) concluded in a study entitled Occupational Stress and its Relation with leaving the organization in small and medium enterprises, that there is a relationship between stress and the intention to leave the organization. They also showed that job satisfaction, emotional commitment, and organizational support are mediators of stress and intent to leave the organization.

Cooper (1998) sought to determine the occupational stress of high school administrators. His research results showed that stressors include issues such as empowering others, discussions about students, and planning and time management skills.

Macan (2002) in his research showed that employees with time control have less job stress and more job satisfaction.

In summary, with a review of studies on work life quality, family cohesion, stress conflicting methods and time management, and the researches about the relationship between them, it is concluded that in some aspects, there are relationship between stress conflicting techniques training and time management with the work life quality and family cohesion.

\section{Research Method:}

The statistical population consists of all Headquarters staff of the Southern Zagros Gas Company, which are 340 employees. The design is a kind of pretest-posttest with a control group using random sampling.

Sample and Sampling Method: A sample of 30 headquarters employees of the Southern Zagros Gas Company were selected randomly. The sampling method is such that at the beginning, the pretest were collected from all 340 members of statistical population about two variables of family cohesion and work life quality through the questionnaire of work life quality and family cohesion. Then, among those with a score of less than 133 in the work life quality questionnaire and less than 96 in the Family cohesion questionnaire, which consisted of 100 individuals, 15 members were randomly selected as the experimental group and 15 members were selected as the control group. In this way, the two groups of 15 members were studied as a sample.

During the training period, the control group was reduced to 14 and the experimental group was reduced to 12. The reason for the drop in subjects was the transfer of subjects to another place. SPSS software is used to analyze the data. The Manco-Anka method is used to check the changes.

Table 1-1. Descriptive characteristics of the statistical sample based on the type of group

\begin{tabular}{|l|l|l|}
\hline Group Type & Frequency & Percentage \\
\hline Control & 14 & 54 \\
\hline Test & 12 & 46 \\
\hline Total & 26 & 100 \\
\hline
\end{tabular}

As shown in the table above, $54 \%$ of the subjects are in the control group and $46 \%$ in the experimental group.

Hypothesis:

1. Combined training of time management and stress conflicting methods with group technique affects on family cohesion.

2. The combined training of time management and stress conflicting methods has a significant impact on the working life quality. 
Data Analysis:

Table 2-1. Mean and standard deviation of the variables studied in the experimental and control groups

\begin{tabular}{|c|c|c|c|c|c|}
\hline Variable & Cronbach's alpha & Test & & & \\
\hline & & $\begin{array}{l}\text { standard } \\
\text { deviation }\end{array}$ & Mean & $\begin{array}{l}\text { standard } \\
\text { deviation }\end{array}$ & Mean \\
\hline $\begin{array}{l}\text { The pre-test of } \\
\text { working life quality }\end{array}$ & 0.51 & 10.46 & 121.92 & 8.57 & 124.07 \\
\hline $\begin{array}{l}\text { The post-test of the } \\
\text { working life quality }\end{array}$ & 0.84 & 15.81 & 126.08 & 13.25 & 143.14 \\
\hline $\begin{array}{l}\text { The pre-test of family } \\
\text { cohesion }\end{array}$ & 0.56 & 9.36 & 81.67 & 7.13 & 86.86 \\
\hline $\begin{array}{l}\text { The post-test of } \\
\text { family cohesion }\end{array}$ & 0.79 & 6.51 & 101.25 & 8.48 & 86.14 \\
\hline $\begin{array}{l}\text { The pre-test of the } \\
\text { relationship }\end{array}$ & 0.80 & 0.45 & 2.79 & 0.43 & 2.92 \\
\hline $\begin{array}{l}\text { The pre-test of } \\
\text { security }\end{array}$ & 0.85 & 0.82 & 1.87 & 0.93 & 2.53 \\
\hline $\begin{array}{l}\text { The pre-test of } \\
\text { Progress }\end{array}$ & 0.42 & 0.38 & 1.62 & 0.33 & 1.90 \\
\hline $\begin{array}{l}\text { The pre-test of } \\
\text { Participatory }\end{array}$ & 0.53 & 0.42 & 1.52 & 0.21 & 1.84 \\
\hline $\begin{array}{l}\text { The pre-test of } \\
\text { Human rights }\end{array}$ & 0.78 & 0.57 & 2.20 & 0.50 & 1.77 \\
\hline $\begin{array}{l}\text { The pre-test of the } \\
\text { balance between work } \\
\text { and life }\end{array}$ & 0.60 & 0.46 & 2.95 & 0.34 & 2.40 \\
\hline $\begin{array}{l}\text { The pre-test of job } \\
\text { commitment }\end{array}$ & 0.69 & 0.32 & 2.77 & 0.39 & 2.84 \\
\hline The financial pre-test & 0.90 & 0.68 & 1.82 & 0.68 & 1.90 \\
\hline $\begin{array}{l}\text { The post-test of the } \\
\text { relationship }\end{array}$ & 0.89 & 0.53 & 2.58 & 0.64 & 3.01 \\
\hline $\begin{array}{l}\text { The Post-test of job } \\
\text { security }\end{array}$ & 0.83 & 0.62 & 1.65 & 1.01 & 2.77 \\
\hline $\begin{array}{l}\text { The post-test of job } \\
\text { progress }\end{array}$ & 0.77 & 0.62 & 1.65 & 0.46 & 2.15 \\
\hline $\begin{array}{l}\text { The post-test of } \\
\text { participation }\end{array}$ & 0.79 & 0.57 & 1.60 & 0.55 & 2.44 \\
\hline $\begin{array}{l}\text { The post-test of } \\
\text { human rights }\end{array}$ & 0.78 & 0.54 & 2.13 & 0.64 & 2.31 \\
\hline $\begin{array}{l}\text { The post-test of the } \\
\text { balance between work } \\
\text { and life }\end{array}$ & 0.38 & 0.22 & 3.06 & 0.44 & 2.75 \\
\hline $\begin{array}{l}\text { The Post-test of job } \\
\text { commitment }\end{array}$ & 0.67 & 0.46 & 3.07 & 0.32 & 3.32 \\
\hline $\begin{array}{l}\text { The financial Post- } \\
\text { test }\end{array}$ & 0.79 & 0.661 & 2.07 & 0.47 & 2.41 \\
\hline
\end{tabular}

Investigation of the Research Hypotheses

Hypothesis 1: Combined training in time management and stress conflicting methods with group technique is effective on work life quality. 
In order to evaluate the effectiveness of combined training of time management and stress conflicting methods in group technique on working life quality, a comparison of the post-test score of the control and experimental group was performed using multivariate covariance analysis (MANCOVA). In this analysis, the pre-test score, was introduced as the control variable and the post-test score was considered as the dependent variable.

Table 1-3) Descriptive indices of two groups of control and experiment in the post-test score of the studied variables.

\begin{tabular}{|l|l|l|l|l|}
\hline \multirow{4}{*}{ The post-test of the working life quality } & Group & Mean & $\begin{array}{l}\text { standard } \\
\text { deviation }\end{array}$ & $\begin{array}{l}\text { Mean } \\
\text { standard } \\
\text { error }\end{array}$ \\
\hline \multirow{3}{*}{ The Post-test of relationships } & & & & 3.77 \\
\cline { 2 - 5 } & experiment & 127.70 & 15.98 & 4.17 \\
\hline \multirow{2}{*}{ The Post-test of job safety } & control & 3.13 & 0.55 & 0.16 \\
\cline { 2 - 5 } & experiment & 2.66 & 0.50 & 0.18 \\
\hline \multirow{2}{*}{ The Post-test of the progress } & control & 2.88 & 0.93 & 0.26 \\
\cline { 2 - 5 } & experiment & 2.20 & 0.73 & 0.28 \\
\hline \multirow{4}{*}{ The Post-test of Participation } & control & 2.24 & 0.35 & 0.14 \\
\cline { 2 - 5 } & experiment & 1.59 & 0.58 & 0.16 \\
\hline \multirow{2}{*}{ The Post-test of Human rights } & control & 2.27 & 0.36 & 0.16 \\
\cline { 2 - 5 } & experiment & 1.61 & 0.64 & 0.17 \\
\hline \multirow{2}{*}{$\begin{array}{l}\text { The Post-test of the balance between work } \\
\text { and life }\end{array}$} & control & 2.16 & 0.55 & 0.17 \\
\cline { 2 - 5 } The Post-test of commitment & experiment & 2.06 & 0.54 & 0.19 \\
\cline { 2 - 5 } & experiment & 2.70 & 0.42 & 0.11 \\
\hline The financial post-test & control & 3.28 & 0.24 & 0.12 \\
\cline { 2 - 5 } & experiment & 3.02 & 0.33 & 0.12 \\
\hline & control & 2.41 & 0.50 & 0.13 \\
\cline { 2 - 5 } & experiment & 2.10 & 0.69 & 0.17 \\
\hline
\end{tabular}

Table 4-1 The multiple tests

\begin{tabular}{|l|l|l|l|l|}
\hline effect & & value & F & P< \\
\hline $\begin{array}{l}\text { The pre-test of } \\
\text { life quality }\end{array}$ & Piley effect & 0.40 & 0.83 & NS \\
\hline group & Piley effect & 0.68 & 2.66 & NS \\
\hline
\end{tabular}

Table 1-5. MANCOVA test to compare control and experiment groups in the post-test score of the studied variables.

\begin{tabular}{|c|c|c|c|c|c|c|}
\hline Independent variable & Squared sum & $\mathrm{Df}$ & $\begin{array}{l}\text { Average } \\
\text { squared }\end{array}$ & $\mathrm{F}$ & $\mathrm{P}<$ & source \\
\hline $\begin{array}{l}\text { The post-test of working life } \\
\text { quality }\end{array}$ & 58.86 & 1 & 58.86 & 0.38 & NS & \multirow{9}{*}{$\begin{array}{l}7 \\
\overrightarrow{0} \\
1 \\
0 \\
0 \\
0 \\
0 \\
0 \\
0 \\
0 \\
0 \\
0\end{array}$} \\
\hline $\begin{array}{l}\text { The post-test of human } \\
\text { relationships }\end{array}$ & 0.001 & 1 & 0.001 & 0.003 & NS & \\
\hline The post- test of job safety & 0.68 & 1 & 0.68 & 0.95 & NS & \\
\hline The Post-test of the progress & 0.06 & 1 & 0.06 & 0.25 & NS & \\
\hline The Post-test of Participation & 0.01 & 1 & 0.01 & 0.03 & NS & \\
\hline The Post-test of Human rights & 0.07 & 1 & 0.07 & 0.24 & NS & \\
\hline $\begin{array}{l}\text { The Post-test of the balance } \\
\text { between work and life }\end{array}$ & 0.001 & 1 & 0.001 & 0.01 & NS & \\
\hline The Post-test of commitment & 0.45 & 1 & 0.45 & 2.95 & NS & \\
\hline The financial post-test & 0.67 & 1 & 0.67 & 2.01 & NS & \\
\hline The post-test of working life & 1532.98 & 17 & 1532.98 & 9.81 & 0.006 & $\sigma \cong$ \\
\hline
\end{tabular}




\begin{tabular}{|l|l|l|l|l|l|l|}
\hline quality & & & & & \\
\hline $\begin{array}{l}\text { The post-test of human } \\
\text { relationships }\end{array}$ & 1.12 & 17 & 1.12 & 3.81 & $\mathrm{NS}$ \\
\hline The post- test of job safety & 2.31 & 17 & 2.31 & 3.21 & $\mathrm{NS}$ \\
\hline The Post-test of the progress & 2.11 & 17 & 2.11 & 9.29 & 0.007 \\
\hline The Post-test of Participation & 2.16 & 17 & 2.16 & 8.04 & 0.01 \\
\hline The Post-test of Human rights & 0.05 & 17 & 0.05 & 0.16 & $\mathrm{NS}$ \\
\hline $\begin{array}{l}\text { The Post-test of the balance } \\
\text { between work and life }\end{array}$ & 0.65 & 17 & 0.65 & 4.95 & 0.04 \\
\hline The Post-test of commitment & 0.34 & 17 & 0.34 & 2.26 & $\mathrm{NS}$ \\
\hline The financial post-test & 0.48 & 17 & 0.48 & 1.44 & $\mathrm{NS}$ & \\
\hline $\begin{array}{l}\text { The post-test of working life } \\
\text { quality }\end{array}$ & 2657.68 & 20 & 2657.68 & & & \\
\hline $\begin{array}{l}\text { The post-test of human } \\
\text { relationships }\end{array}$ & 4.99 & 20 & 4.99 & & \\
\hline The post- test of job safety & 12.22 & 20 & 12.22 & & \\
\hline The Post-test of the progress & 3.86 & 20 & 3.86 & & \\
\hline The Post-test of Participation & 4.56 & 20 & 4.56 & & \\
\hline The Post-test of Human rights & 5.36 & 20 & 5.36 & & \\
\hline $\begin{array}{l}\text { The Post-test of the balance } \\
\text { between work and life }\end{array}$ & 2.23 & 20 & 2.23 & & \\
\hline The Post-test of commitment & 2.56 & 20 & 2.56 & & \\
\hline The financial post-test & 5.64 & 20 & 5.64 & & \\
\hline
\end{tabular}

As it can be seen from the results of the table, there is a significant difference between the experiment and control group in the post-test score of working life quality. Since the post-test average of working life quality in the experimental group (127.70) is less than the post-test average working life quality in the control group (145.53), so the hypothesis is not confirmed. But in the term of balance between work and life, since the post-test average of the experimental group (3.06) is higher than the average of control group (2.70), therefore the balance between work and life in the experimental group is more than the control group. It means that the combined training of time management and stress conflicting methods using group technique has a significant effect on the balance between work and life.

Second hypothesis: Combined training of time management and stress conflicting strategies in a group way is effective on family cohesion.

Covariance analysis, ANCOVA, was used to compare the control and experimental group in the post-test score of family cohesion. In this test, the control variable "family cohesion pre-test score" and dependent variable "post-test score of family cohesion" were considered.

Table 1-6) Descriptive indices of control and experiment groups in the post-test variable of family cohesion.

\begin{tabular}{|l|l|l|l|}
\hline Group & Average & Standard deviation & Mean standard error \\
\hline Control & 84.71 & 8.48 & 1.64 \\
\hline Experiment & 102.90 & 6.51 & 1.77 \\
\hline
\end{tabular}

Table 1-7. Results of covariance analysis test to compare the control and experimental group in post-test score of family cohesion.

\begin{tabular}{|l|l|l|l|l|l|}
\hline $\begin{array}{l}\text { Sources of } \\
\text { variance }\end{array}$ & squares sum & Df & mean squares & F & P< \\
\hline $\begin{array}{l}\text { The pre-test of } \\
\text { cohesion }\end{array}$ & 581.25 & 1 & 581.25 & 16.29 & 0.001 \\
\hline Group & 1935.53 & 1 & 1935.53 & 54.24 & 0.001 \\
\hline Error & 820.71 & 23 & 35.68 & & \\
\hline
\end{tabular}

As can be found from the table results, there is a significant difference between the experimental and control groups. Since the average post-test of the experimental group (102.90) is higher than the average post-test of the control group (84.71), family cohesion in the experimental group is more than the control group. That 
means combined training of time management and stress conflicting strategies in a collective manner affects family cohesion.

\section{Conclusion}

This paper examines the effectiveness of combined training of stress conflicting and time management methods in a group manner on the quality of working life and the family cohesion of the Southern Zagros gas company's headquarter staff. The experimental group was educated at 8 sessions, once a week, Stress conflicting strategies (training of the cognitive behavioral conflicting methods including cognition and cognitive error correction, positive thinking, healthy thinking, mental imagery and problem solving skill, role of nutrition, sleep and exercise, training of correct respiratory pattern ) And time management (telephone conversations, unorganized meetings and visits, distraction reasons in the environment, etc.), but the control group did not receive any training. The statistical analysis of data does not confirm the effectiveness of combined training of time management and stress conflicting strategies in a group manner on the working life quality of the Southern Zagros gas company's staff. Considering the fact that most of the participants in the experimental group were contractors in terms of employment status and in terms of salary, benefits, career progression, job security and participation were lower than the formal and subordinate employees, these factors made the first hypothesis insignificant.

Since a person in an organization faces different organizational variables and most of these variables are beyond the control of the individual, then by training, one can only reinforce individual skills and other organizational variables are related to the structure of the organization, and the organizational structure change is beyond the control of the individual. Therefore, the issue of work life quality depends more on the dimensions of organizational structure and manager style, but in the balance between work and life, which is one of the work life quality components, integrated training of time management and stress conflicting strategies in group manner is meaningfully effective. This means that by combined training of time management and stress conflicting strategies, family cohesion can be increased for the staff's family.

\section{References}

Corey, M.S.\& Corey, G. , 1998 , Be coming a helper. Pacific Grove, CA : Brooks / colepublishing company Dienhart, John R.,1993,Jobsatisfaction,Job Involvement,Security \&Customer Focus ofService Restaurant Employees ,.Journal of Hospitality\&tourism Research,vol.16,no.2.

Dixie,Villanueva.,Nikola,Djurkovica.,2009,Occupational StressP\&Intention to Leave Among Employees inSmall\&medium Enterprises, aschool of Manage ment, la Trobe university.

Farner Jack D. , 2001 , success ful Time management . newyork-U.S.A

Hartos , J.L., power , T.V., 2000 , Association between mother \& adolescent report for relations between parent-addescent communication \& adolescent adjustment. Journal of youth \& Adolescence, vol.24, pp.441-451.

Ma can ,TH . , 2002, Redesigening the term paper one example of howtoengage students Focus on teaching and technology conference, st. Louis, Mo, November

Ma can ,TH ., 2002, Redesigening the term paper one example of howtoengage students Focus on teaching and technology conference, st. Louis, Mo , November

Olson , D.H. , 1999 , circumplex model of marital \& family systems . Journal of family therapy, vol.22 , p.144-167.

Powers, Vicki. ,2004, Keeping Work \& Live In BalanceDmagazine, v.58,p.32-35.

Saraji Nasl \& H.Dargahi, 2006, study of Quality of work Life (QWL), Iranian J.public Health, Vol.35.

Victoria c.L, Naomi ,B. , 2006 , family cohesion and children' behavior problems . Alongi tudinal investigation . psychiatry Research, vol.141, Issue p.141-149 